\title{
Fears of humanitarian crisis in western Myanmar's camps for internally displaced persons
}

$\mathrm{L}$

unch time offers 20-year-old Arafa Begum a rare moment of privacy in the eight-by-sixmetre tent she shares with eight other families. As communal pots outside are heated and filled with rice rations, she stays behind with a few other women for a chance to breastfeed her six-month-old daughter.

"There is no clean space here," says Begum, as she crouches on the dirt floor, cradling her baby. She says that because of her meagre diet she sometimes struggles to lactate. "The baby is always crying because I don't have enough milk."

Begum is a member of the Rohingya Muslim minority group. She lives in a temporary encampment outside of Sittwe, the capital of Rakhine, a state in western Myanmar that last year convulsed with sectarian violence between Buddhists and Muslims. At least 167 people were killed, some 10000 homes destroyed, and around 140000 people — the vast majority Rohingya Muslims — displaced.
Myanmar, also known as Burma, is a Buddhist-majority country with a long history of ethnic- and religiousbased civil conflict.

Begun and the roughly 4000 internally displaced people (IDPs) in her camp were driven from their homes last June. As the one-year anniversary of their violent upheaval approaches along with the onset of a several-month period of torrential rain, aid groups are warning of a potential humanitarian crisis.

The monsoon season, which starts this month, brings heavy rainfall almost daily, and extreme storms and even cyclones are not uncommon; a cyclone in 2010 left 100000 people in Rakhine homeless. Already this month, Rakhine narrowly averted catastrophe when a cyclone veering towards the area dissipated before it made landfall, though dozens of Rohingyas drowned when their boat capsized during emergency evacuations.

Roughly half of all IDPs are still living in camps in flood-prone areas, and another 5000 are housed in flimsy shelters - usually fabricated of nothing more than thatched straw - that offer little protection from heavy rain, according to the United Nations. For these IDPs, the government and international aid groups are scrambling to construct raised shelters that would remain elevated above floodwaters.

Even prior to the monsoon season, conditions in the camps were bleak. An assessment last December by an international nongovernmental organization (NGO) found that among children ages 6-59 months in IDP camps around Sittwe, $14.4 \%$ suffered from acute malnutrition. This rate is just below the World Health Organization's threshold of $15 \%$ for it to confer "emergency" status on a refugee or IDP population.

Médecins Sans Frontières (MSF) has already reported high cases of respiratory and skin infections, worms and diarrhea in the camps, and warns that the prevalence of such ailments could multiple, alongside new health issues, during the monsoon. Dorian Job, health director for MSF in Myanmar, says his

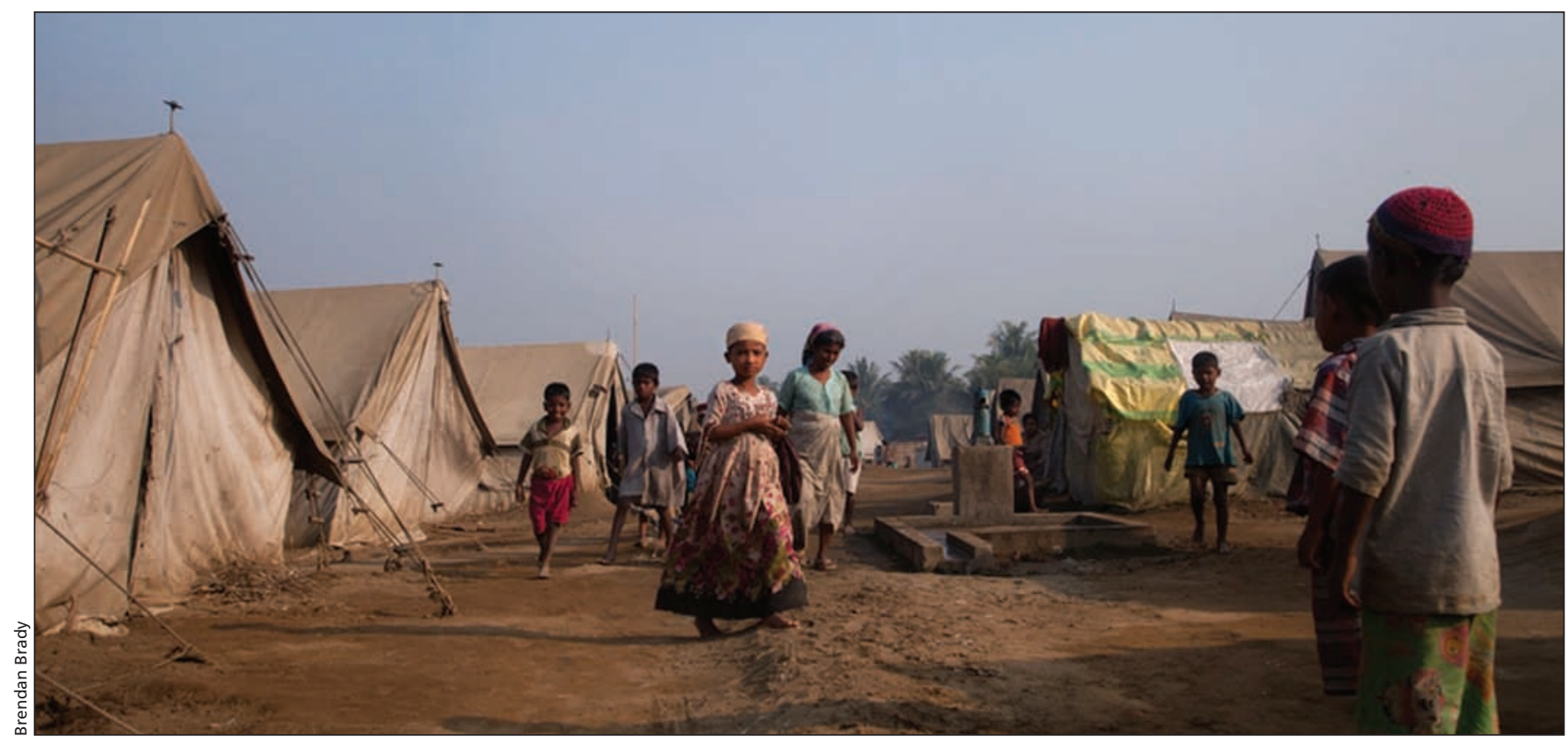

Children play in the midst of a temporary, overcrowded camp for 4000 people near Sittwe, Myanmar. 
medical teams are already observing an increase in malaria cases because of the spread of rainwater pools where mosquitos breed. Many malaria-stricken IDPs don't have access to treatment.

Flooding from monsoon rains will result in a "rapid deterioration" of shelter, sanitation and health conditions, the United Nations warned in a report in March. The report added typhoid, viral hepatitis and leptospirosis to the list of diseases threatening to spread in the camps under monsoon conditions.

"Latrine pits will get flooded, and feces will spread in the at-risk camps," stated the report. "Shallow hand pumps will get flooded and contaminated by both floodwater and underground water contamination by latrine pits."

Monitors have sharply criticized the government for not taking pre-emptive measures against such threats months ago.

"The Burmese government didn't heed the repeated warnings by governments and humanitarian aid groups to relocate displaced Muslims ahead of Burma's rainy season," the international rights group Human Rights Watch stated (www.hrw.org/node/115513) May 14. "If the government fails to evacuate those at risk, any disaster that results will not be natural, but man-made."

International rights groups allege the inaction has much to do with official discrimination against the Rohingya, who are denied citizenship by a 1982 law enacted by the country's then-military dictatorship. The Rohingya are regarded by the government and wider Burmese public as interlopers because their roots in Myanmar are shorter than those of most other ethnic groups in the country, and because of their evident religious, linguistic and physical differences.

Since 2011, Myanmar has transitioned away from military dictatorship to semi-civilian rule and instituted a series of democratic reforms. But, despite calls from rights groups outside the country, the policy of classifying all Rohingyas as illegal immigrants has not been changed.

Hostility towards the Rohingya has also affected medical teams, who have reported being intimidated and blocked from travelling to Rohingya camps by local hardline Buddhists (www.msf .org/article/myanmar-humanitarian -emergency-rakhine-state).

Such hindrances were what left 42year-old Noor Bahar suffering with tuberculosis in a camp for months before she was able to leave to receive treatment. Local Buddhist communities had blocked relief groups from delivering food or medical provisions to her isolated mountaintop camp. She was able to travel to a clinic near Sittwe only after a high-profile UN representative visited her camp in February and brought her out, along with a small con- tingent of other IDPs in critical condition, in his convoy.

But it was only exceptional circumstances that allowed her to escape possible death. She said one of her relatives was coughing up blood and passing blood through his stool but was unable to receive medical care in the camp or leave to seek treatment elsewhere.

There are also, according to United Nations estimates, some 15000 displaced Rohingyas who have not been allowed to register as official IDPs and therefore are denied access to humanitarian aid.

Abject suffering has pushed increasing numbers of Rohingyas to turn to desperate measures to escape their current conditions.

Chris Lewa, who heads the Arakan Project, an NGO that tracks rights abuses in Rakhine, estimates that nearly 28000 Rohingyas attempted to flee by sea over the past six months - three times the previous rate. Travelling the high seas on rickety fishing barges, with few supplies, many of die of starvation, dehydration or drowning.

"They now feel that there is no longer any future for them in Rakhine," says Lewa. "They have lost the little bit of hope that their situation could ever improve." - Brendan Brady, Sittwe, Myanmar

CMAJ 2013. DOI:10.1503/cmaj.109-4506 